\title{
STUDI KOMPARATIF KINERJA PETUGAS SURVEILANCE EPIDEMIOLOGI PUSKESMAS RIAM DURIAN KABUPATEN SUKAMARA
}

\author{
${ }^{1}$ Christina T. Setiawan,S.kp.,M.Kes \\ ${ }^{1}$ STIKes Borneo Cendekia Medika Pangkalan Bun \\ 1 csetiawan.366@gmail.com
}

\begin{abstract}
ABSTRAK
Indikator pelaksanaan surveilans epidemiologi adalah tersedianya tenaga epidemiologi minimal satu orang, tersedianya data terkini. Kinerja petugas surveillance epidemiologi di Kabupaten Sukamara. Kinerja responden petugas survailance epidemiologi puskesmas di Riam Durian Kabupaten Sukamara antara wilayah barat dan selatan timur sama-sama memiliki kinerja baik masing-masing sebanyak 50\% (9 responden dan 9 responden). Kinerja responden petugas survailance epidemiologi Puskesmas Riam Durian Kabupaten Sukamara antara wilayah barat dan selatan timur sama-sama memiliki kinerja baik, Tidak ada komparatif kinerja petugas survailance epidemiologi Puskesmas Riam Durian Kabupaten Sukamara Kualitas petugas perlu ditingkatkan dengan mengadakan refreshing terhadap adanya perkembangan keilmuan pada strategi yang bisa digunakan petugas survailance epidemiologi
\end{abstract}

\section{Kata kunci : Surveilance Epidemiologi}

\author{
COMPARATIVE STUDY OF THE PERFORMANCE OF SURVEILANCE \\ EPIDEMIOLOGY OF THE HEALTH CENTER OF RIAM DURIAN SUKAMARA \\ DISTRICT
}

\section{ABSTRACT}

The indicator of the implementation of epidemiological surveillance is the availability of epidemiology personnel of at least one person, the availability of the latest data. Performance of epidemiological surveillance officers in Sukamara District. The performance of respondents in the epidemiology survey of puskesmas in Riam Durian, Sukamara Regency between the western and southern eastern regions both had a good performance of 50\% each (9 respondents and 9 respondents). The performance of respondents in epidemiology survailance officers Riam Durian Health Center Sukamara District between the western and south eastern regions are equally good. There is no comparative performance of epidemiological surveillance officers Riam Durian Health Center in Sukamara District Sukamara Quality of officers needs to be improved by conducting a refreshing on the development of knowledge on strategies that can used by epidemiological surveillance officers

\section{Kata kunci : Surveilance Epidemiologi}




\section{PENDAHULUAN}

Indikator pelaksanaan surveilans epidemiologi adalah tersedianya tenaga epidemiologi minimal satu orang, tersedianya data terkini, kelengkapan pelaporan secara menyeluruh dari jenis pelaporan seperti pelaporan program kesehatan ibu dan anak, pelaporan Kejadian Luar Biasa, pelaporan penemuan kasus-kasus baru dari penyakit menular dan berbagai jenis pelaporan lainnya yang terakomodir dalam sistem pencatatan dan pelaporan terpadu serta ketepatan waktu pelaporan. Berdasarkan profil kesehatan Indonesia (2008), tenaga epidemiologi di seluruh kabupaten/kota di Indonesia belum merata. Hal ini terlihat dari rendahnya rasio tenaga epidemiologi terhadap jumlah puskesmas yaitu hanya 0,5 per 1000 puskesmas dari 8.234 unit puskesmas Indonesia. Permasalahan yang terkait dengan sumber daya manusia kesehatan adalah penyebaran tenaga kesehatan yang belum merata, mutu pendidikan belum seperti yang diharapkan dan komposisi tenaga kesehatan yang masih belum seimbang. Sedangkan pada kebutuhan tenaga kesehatan belum mengacu pada beban kerja serta aspek pelayanan yang berbasis kewilayahan misalnya puskesmas. Saat ini hampir semua petugas kesehatan memiliki beban kerja tinggi dengan merangkap berbagai program atau pekerjaan sehingga tidak fokus dan konsentrasi penuh dalam menyelesaikan pekerjaan. Keberhasilan pelaksanaan surveilans epidemiologi menjadi indikator kinerja puskesmas dan kinerja dinas kesehatan secara keseluruhan. Kinerja surveilans epidemiologi dilihat dari beberapa indikator khususnya pada indikator proses yaitu (1) kelengkapan laporan unit pelaporan dan sumber data awal $\geq 80 \%$, (2) ketepatan laporan unit pelapor dan sumber data awal $\geq 80 \%$, (3) penerbitan buletin kajian epidemiologi sebesar 4 kali atau lebih setahun, dan (4) adanya umpan balik sebesar $80 \%$ atau lebih terhadap permasalahan yang dihadapi.

\section{METODOLOGI PENELITIAN}

Metode penelitian kuantitatif dalam penelitian ini menggunakan penelitian komparatif. Populasi dalam penelitian ini adalah seluruh petugas pelaksana survailance eidemiologi puskesmas teknik sampling yang digunakan dalam penelitian ini adalah total sampling. Skala data dari variable adalah katagorik sehingga data tidak berdistribusi normal dan tidak homogeny sehingga uji yang di gunakan adalah uji Man Whitney.

\section{HASIL PENELITIAN}

A. Data umum

\section{a. Umur}

$\begin{array}{llr}\text { Tabel } & \text { Distribusi } & \text { frekuensi } \\ 1 & \text { umur } & \text { responden } \\ & \begin{array}{l}\text { petugas } \\ \text { epidemiologi }\end{array} & \\ & \text { survailance } \\ & \text { puskesmas } & \text { Riam } \\ & \begin{array}{l}\text { Durian } \\ \text { Sukamara. }\end{array} & \text { Kabupaten } \\ & \end{array}$

\begin{tabular}{lcc}
\hline Umur & Frekuensi & Prosentase \\
\hline $\begin{array}{l}\text { Kurang } \\
\text { dari 30 th }\end{array}$ & 2 & 11.1 \\
$\begin{array}{l}\text { 30-50 th } \\
\text { Lebih } \\
\text { dari 50 th }\end{array}$ & 14 & 77.8 \\
Total & 18 & 11.1 \\
\hline
\end{tabular}

Berdasarkan tabel 1 lebih dari separuh Umur Responden petugas survailance 
epidemiologi puskesmas Riam Durian Kabupaten Sukamara. berumur 30 - 50 tahun sebanyak $77,8 \%$ (14 responden ) .

\section{b. Jenis Kelamin}

Tabel 2 Distribusi frekuensi jenis kelamin responden petugas survailance epidemiologi puskesmas Riam Durian Kabupaten Sukamara.

\begin{tabular}{lcc}
\hline $\begin{array}{c}\text { Jenis } \\
\text { kelami } \\
\text { n }\end{array}$ & $\begin{array}{c}\text { Freku } \\
\text { ensi }\end{array}$ & $\begin{array}{c}\text { Prose } \\
\text { ntase }\end{array}$ \\
\hline $\begin{array}{l}\text { Perem } \\
\text { puan }\end{array}$ & 7 & 38.9 \\
$\begin{array}{l}\text { Laki- } \\
\text { laki }\end{array}$ & 11 & 61.1 \\
Total & 18 & 100.0 \\
\hline
\end{tabular}

Berdasarkan tabel 2 lebih dari separuh jenis kelamin responden petugas survailance epidemiologi puskesmas Riam Durian Kabupaten Sukamara berjenis kelamin laki-laki sebanyak 61,1 $\%$ ( 11 responden ).

c. Masa Kerja

Tabel Distribusi frekuensi masa 3 kerja responden petugas survailance epidemiologi puskesmas Riam Durian Kabupaten Sukamara.

Berdasarkan tabel 3 lebih dari separuh masa kerja responden petugas survailance epidemiologi puskesmas Riam Durian Kabupaten Sukamara memiliki masa kerja lebih dari 10 tahun sebanyak 61,1\% (11 responden).
B. Data khusus

a. Kinerja

Berdasarkan hasil uji didapatkan kinerja responden petugas survailance epidemiologi puskesmas Riam Durian Kabupaten Sukamara antara wilayah barat dan selatan timur sama-sama memiliki kinerja baik masing-masing sebanyak $50 \%$ (9 responden dan 9 responden).

b. Komparatif Kinerja

Skala data dari variable adalah katagorik sehingga data tidak berdistribusi normal dan tidak homogen sehingga uji yang di gunakan adalah uji Man Whitney. Hasil uji statistik man whitney didapatkan $p=0.150 \quad(p>0.05)$ yang artinya tidak ada komparatif kinerja petugas survailance epidemiologi Puskesmas Riam Durian Kabupaten Sukamara.

\section{PEMBAHASAN}

A. Kinerja petugas surveillance epidemiologi di Kabupaten Sukamara

Kinerja responden petugas survailance epidemiologi puskesmas di Riam Durian Kabupaten Sukamara antara wilayah barat dan selatan timur sama-sama memiliki kinerja baik masing-masing sebanyak 50\% (9 responden dan 9 responden).

Petugas survailance epidemiologi melaksanakan tugas dan tanggung jawabnya sesuai yang dibebankan. Kinerja merupakan aktivitas manusia yang diarahkan pada pelaksanaan tugas organisasi yang dibebankan kepadanya. Kinerja 
baik yang sudah dilakukan dipengaruhi oleh berbagai hal, efektifitas dan efisiensi dari tujuan organisasi, pelaksanaan disiplin yang termonitor, adanya wewenang yang diberikan, serta petugas memiliki inisiatif untuk menyelesaikan tugas serta kewajibannya.

Pada tabel 1 lebih dari separuh umur Responden petugas survailance epidemiologi puskesmas Riam Durian Kabupaten Sukamara berumur 30 - 50 tahun sebanyak 77,8 \% (14 responden). Usia petugas survailance epidemiologi berada pada masa produktif, sehingga tugas dan tanggung jawab yang diberikan kepadanya dapat diselesaikan dengan baik. Pegawai yang berusia lebih tua cenderung lebih mempunyai rasa keterikatan atau komitmen pada organisasi dibandingkan dengan yang berusia muda sehingga meningkatkan loyalitas mereka pada organisasi.

Pada tabel 2 lebih dari separuh jenis kelamin responden petugas survailance epidemiologi puskesmas Riam Durian Kabupaten Sukamara memiliki jenis kelamin laki-laki sebanyak 61,1 \% (11 responden). Dalam melaksanakan tugas beban yang diberikan kepada petugas berjenis kelamin perempuan maupun lakilaki adalah sama. Menurut Robbins (2003) menyatakan bahwa tidak ada perbedaan yang konsisten antara pria dan wanita dalam kemampuan memecahkan masalah, ketrampilan analisis, dorongan kompetitif, motivasi, sosiabilitas atau kemampuan belajar.
Pada tabel 3 lebih dari separuh masa kerja responden petugas survailance epidemiologi puskesmas Riam Durian Kabupaten Sukamara memiliki masa kerja lebih dari 10 tahun sebanyak $61,1 \%$ (11 responden).

$$
\text { Masa kerja (lama }
$$

bekerja) merupakan pengalaman individu yang akan menentukan pertumbuhan dalam pekerjaan dan jabatan. Menurut Kreitner dan Kinicki (2004) masa kerja yang lama akan cenderung membuat seorang pegawai lebih merasa betah dalam suatu organisasi, hal ini disebabkan diantaranya karena telah beradaptasi dengan lingkungannya yang cukup lama sehingga seorang pegawai akan merasa nyaman dengan pekerjaannya. Penyebab lain juga dikarenakan adanya kebijakan dari instansi atau perusahaan mengenai jaminan hidup di hari tua.

B. Komparatif Kinerja petugas surveillance epidemiologi di Kabupaten Sukamara.

Berdasarkan hasil uji statistik didapatkan Asymp Sig terlihat bahwa nilai probabilitas 0.150 . Sehingga keputusan yang diambil adalah H0. (1>0.05) Jadi tidak ada komparatif kinerja petugas survailance epidemiologi Puskesmas Riam Durian Kabupaten Sukamara.

\section{Semua} petugas melaksanakan tugas dan tanggung jawab sesuai dengan kemampuan wewenang yang diberikan oleh pihak manajemen. Jelas terlihat dengan adanya kinerja yang baik yang sudah dilaksanakan petugas 
survailance epidemiologi berarti telah mengikuti tata cara atau prosedur sesuai standar yang telah ditetapkan. Terdapat peran langsung keikutsertaan Dinas Kesehatan Kabupaten Sukamara dan manajemen Puskesmas untuk bisa mengkontrol dan memberikan teknik cara agar bagaimana bisa terjaminnya mutu dan kualitas sehingga petugas bisa dengan mudah bekerja tanpa ada rasa terbebani dan otomatis hubungan antara pihak manajemen dengan petugas semakin baik dan kuat.

\section{KESIMPULAN DAN SARAN}

\section{Kesimpulan}

Kinerja responden petugas survailance epidemiologi Puskesmas Riam Durian Kabupaten Sukamara antara wilayah barat dan selatan timur sama-sama memiliki kinerja baik, Tidak ada komparatif kinerja petugas survailance epidemiologi Puskesmas Riam Durian Kabupaten Sukamara.

\section{Saran}

a. Dinas Kesehatan

Manajemen dinas kesehatan mempertahankan kinerja petugas survailance epidemiologi. Kualitas petugas perlu ditingkatkan dengan mengadakan refreshing terhadap adanya perkembangan keilmuan pada strategi yang bisa digunakan petugas survailance epidemiologi.

b. Puskesmas

Manajemen

Puskesmas mempertahankan komunikasi efektif dengan petugas survailance epidemiologi. Memberikan kesempatan untuk bisa mengembangkan pengetahuan tentang survailance epidemiologi.

c. Petugas Surveilance Epidemiologi Mempertahankan kinerja yang sudah dilaksanakan selama ini dengan tetap mengembangkan wawasan pengetahuan terkait survailance epidemiologi.

d. Peneliti Selanjutnya

Peneliti selanjutnya dapat melakukan penelitian terkait factor-faktor yang mempengaruhi kinerja petugas survailance epidemiologi.

\section{DAFTAR PUSTAKA}

Amstrong, Mischael, 1999.

Manajemen Sumber Daya

Manusia. Terjemahan Sofyan

dan Haryanto. PT. Elex Media

Komputindo. Jakarta.

Luthans, F. 2005. Organizational Behavior. New York: McGrawhill.

Mangkunegara, Anwar Prabu . 2002. Manajemen Sumber Daya Manusia. Remaja Rosdakarya. Bandung

Murti, B. 2003. Prinsip dan Metode Riset Epidemiologi. Jakarta: Gadjah Mada University Press

Mathis, R.L. \& J.H. Jackson. 2006. Human Resource Management: Manajemen Sumber Daya 
Manusia. Terjemahan Dian Angelia. Jakarta: Salemba Empat. Nurlaila, 2010. Manajemen Sumber Daya Manusia I. Penerbit LepKhair.

Profil kesehatan Kabupaten Bojonegoro, 2015

Prawirosentono, Suryadi. 1999. Kebijakan Kinerja Karyawan. Yogyakarta: BPFE.

Robbins, Stephen P., 2006. Perilaku Organisasi, PT Indeks, Kelompok Gramedia, Jakarta.

Rivai, Vethzal \& Basri. 2005. Peformance Appraisal: Sistem yang tepat untuk Menilai Kinerja Karyawan dan Meningkatkan Daya Saing Perusahan. Jakarta: PT. RajaGrafindo Persada.

Robbins, Stephen P., 1996. Perilaku Organisasi Jilid II, Alih Bahasa
HadayanaPujaatmaka, Jakarta, Prenhalindo. 